\title{
The impact of Consumer Awareness on buying behavior of green products
}

\author{
Manveer Kaur ${ }^{1}$, Dr. Ambika Bhatia ${ }^{2}$ \\ ${ }^{1}$ Punjabi University, Patiala, India \\ ${ }^{2}$ Punjabi University Regional Centre for IT \& Management,Mohali, India
}

\begin{abstract}
Consumer awareness towards the organic, eco-friendly or green products is important in guiding them towards the purchase intention and further favors the buying behavior. This study aims to identify the influence of consumer's environmental concerns, awareness of green product, and brand image on their buying decision of eco-friendly products. Companies try to produce natural products to meet the need and satisfaction of the people. Major determinants that impacts consumer awareness and further leads them to buy green products are safety, income, ecological concern, knowledge, age , gender, attitude, values, brand labelling, packaging etc. this study provides valuable insights into the consumer buying behavior by studying the consumer awareness. Compared to consumer awareness in developed countries Indian consumers are still less aware of the environmental issues. This paper reviews the work of researches and aims to define the impact consumer awareness have on the purchasing behavior of the organic or green products.
\end{abstract}

Keywords: social awareness, consumer awareness, appearance consciousness, brand image, green marketing

\section{INTRODUCTION}

Green movement is increasing rapidly around the globe. With developing nations being more concern towards the environment, compared to the developing nations being less aware towards the benefits of going green, there is still a gap of awareness in India.Environemntal problems such as soil, air , water pollution and other catastrophic issues have been repeatedly taken which raises issues making people concern towards the environment, and leading government focussed towards the nature.

\section{CONSUMER AWARENESS}

Awareness about green products is the basic idea which transcends people to think positively towards the problems being faced by the environment as well as the people. Today, several companies have realised their responsibility towards the deteriorating environment and have come forward to market their products as green, eco-friendly or organic, it can reduce pollution to a certain extent and simultaneously adds to the profit margin (Sujith $\mathrm{T}$ S). Mc Donald and Sharp explained in their study "the impact of awareness on purchase intention "that even if consumers want to purchase a certain product, brand recognition plays a vital role. Laroche et al. (2001) in his research studied quite a handful of literature review on what factors persuade

the buying behaviour of consumers for green or natural products. He further classified his research into 5 categories namely - knowledge, demographics, values and attitudes, behaviour.

Boztepe 2012 examined that environmental awareness, green promotional activities are the factors that could impact the buying behaviour of the people in a positive way, Yenoshin and Shinjan 2005 indicated that awareness has a direct impact on the purchasing behaviour of eco-friendly or green products, therefore it was clear that clients who have a thing for the environment and are conscious about the market place will definitely go for green products.

Alarming customers now a days respond to the environmental situation by buying green or ecofriendly products (Barbara forleo 2001), consumers keep a tab on the material used in the product that is if the product is wrapped in the recycling material. Hence awareness about the ecological compatible products (Schlegelmilch \& Diamantopoulos, 1993) leads to the buying behaviour of the natural products, as people feel they are more safe to use. Perhaps, consumer's level of environmental concern is related to their consideration and willingness for buying the natural, eco-friendly or green products. Many experiments conducted earlier reflected that (zimmer, Stafford, 1994) environmental concern is 
playing an important role in the decision making of customers. Furthermore, various studies examined relations between attitudes and behaviour of the consumers and their concern towards the environment (Roberts \& Bacon, 1997). However, some researchers give a different theory, Hume (1991), explained that there is not always a positive relationship between the consumers concern towards the environment and buying behaviour.

\subsection{Consumer attitude, belief's \& values}

Studies also show that people have less opportunity to form an attitude towards the green or organic products than about other (Hoyer and Machhinis, 2004) products, unless they have made a distinct effort to know about the green products, however aspirational and motivational groups do influence the purchase decision of individuals.

Consumers beliefs and values also lead to the buying behaviour of the green products ( Reser and Bentrupper baumer, 2005), it was also seen that environmental values and the concern for environment also positively impacts the pro environmental behaviour.

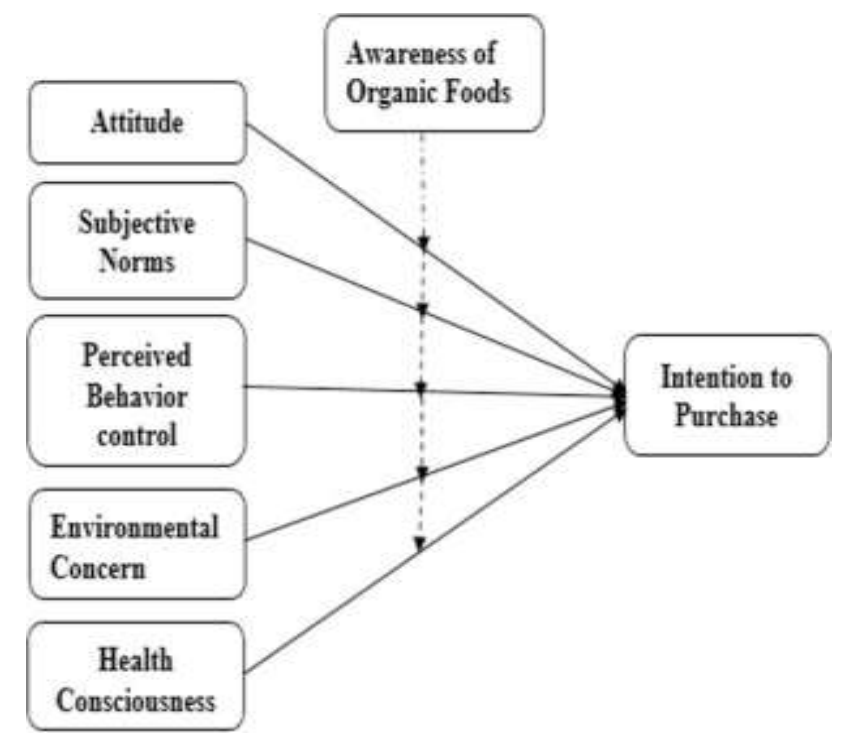

Fig 1

Over the last decade consumption green products and services have increased tremendously. Natural resources are getting depleted regularly (Chai \& Chen , 2010) due to the usage, hence causing damage to the environment Thus it shows that there are lot of determinants of consumer awareness that further help in directing the buying behaviour . Awareness of organic or natural products depends upon the attitude of masses towards the environment; studies have shown that people have asked for the green products (shishime \& Fujitsika, 2012). Although the amount of people who desired for green products, has increased yet there is very little evidence to prove that individuals willing to purchase green products has increased. According to Johs and Killburn , 2011 consumers awareness and attitude towards the buying of green products and concern for the deteriorating environment has just captured $1-3 \%$ of the total market size. This explains that consumer awareness has least impacted the purchase of green products and consumers generally overlook the concept of environmental values and behaviour (Webb and Harris, 2001)

While researching the green purchase behaviour, many studies have expressed discrepancies between the favourable attitudes of the consumers and the actual buying practices.(Hanger 2007) according to him , a large percentage of people showed positive attitude towards the organic products but only a small number of people actually purchased the products. Thus this shows that there exists a gap between the attitude and actual purchase of the organic or green products. A similar study done by Defra in 2006 showed that in United Kingdom 30\% of people have showed their concern towards the environment but hardly purchased or translated their concern. It defines that it is not always necessary that a person's concern will fall into the action. It is therefore needed to study that why there exists a weaker impact or influence towards the environmental concern. Many factors such as price, social behaviour, environmental friendliness, availability etc. that lead to the gap between the attitude and buying behaviour of the green and the natural products. Many researches have also shown that though people understand the seriousness of the environmental issue yet they are reluctant to actual purchase the product (Roka and Uusitalo2008)

Various studies were done to identify the factors influencing the consumer's attitude and behaviour, and the results show that environmental knowledge and concern and the major attributes of products functional as well as green are the major drivers whereas availability and high price are the major barriers towards consumer's green purchasing behaviour.Ajzen in 1985 gave theory of planned behaviour in which he stated that the behaviour of an individual is based on two things-social norms and individual attitude. And in his further research in 1988 he added one more factor to his theory as a determinant of individual behaviour which was PCE (Perceived Consumer Effectiveness)

It was further seen that strong social and environmental values motivate the consumers and increase their involvements in the buying situation. Thus leading the positive and active participation the organic purchase process (Rahman and Aggarwal, 2014).Moreover, Vermeir and Verbeke, 2006), proved that there exists a favourable relationship 
between attitude- behaviour relationship and green purchases .

\subsection{Product Attributes}

A lot of studies(Magnuson et al, 2003) have compared the intensity of the effect of consumer's environmental concern and the product attributes on green buying behaviour. Whereas some studies Some studies have defined that the attributes of the product like healthiness and quality, mainly drive consumers towards the green purchase behaviour (Chen et al., 2012) however other studies have declared altruistic values as the main motivating factors (Padel and Foster, 2005; Tsarenko et al., 2013) . consumers generally look for different environmental, social and individual consequences of a organic purchase of products. Be it peer influence or social refrence groups, some of the ocnsumers overshadow this positive relation and do not evolve the green buying behaviour. That is why some clients show their concern towards the environment and society but do not actually put their concern into actions.

According to (Smith, 2010), consumers take into account the benefits products provide to the individual as well as to the nature or society. For this an individual who is concern and is rational will buy the product which is safe to use for e.g. CFC free, and is in recyclable packaging, is not tested on animals and does not contains the harmful chemicals and pollutants. Further as far as nature is concerned a concerned consumer will ask and look out for products which are green or organic, as they will be made from natural resources and will be free from harmful chemicals. Lastly being green means favourable to use and it also provides a feeling of genuineness and helps the society to propel for the futures to come.

\subsection{Knowledge}

Effective knowledge of social and environmental issues positively affects the green purchasing intention and buying behaviour. Large number of studies has shown that increased Consumer Knowledge (Tanner and Kast, 2003) brings in the trust towards the green products and reinforces the effective relationship of effective and efficient knowledge, contrary to this those individuals who do not have proper knowledge (Vermeir and Verbeke's, 2006) or lack knowledge prevents consumers from translating their concern into the actual buying of green products. However some authors have challenged this theory and said that knowledge has no impact on the buying behaviour of people towards the organic or green products. But a deeper understanding of the benefits of green products make the consumers shift (Mondelaer et al 2009) towards the green products.

Labels also play an important role, if people are aware about the eco-labels or the information that is supplied or printed on the labels does not have sustainability issues. But the problem arises because people do not know the difference between a green label and other labels. A study shows that lack of awareness towards eco-labels and trust in them minimizes the effectiveness of these labels. The above inferences show that eco-labels have no impact towards green purchasing if people do not trust these labels. Hence to make these labels worthy and to make them attracted towards the people, appropriate media or marketing is needed.

\subsection{Environmental and Health consciousness}

Consumer willingness to pay for organic products was studied (George Chryssohoidis ) and the result was declared that purchase intentions were based on the environmental and health consciousness, safety and quality concerns and other specific products also such as nutritional value, price, safety standards, certifications. Study done by Reicks et al in 1997 on socio-demographic profile of the customers agreed that people who go for organic products or green products are mainly women who buy in large quantities as compared to the men who occasionally buy and that too the smaller quantities. Another factor Age was studied and it was declared that number had no effect on the purchasing decision as younger consumers were slightly more willing to consume organic and green products due to their greater environmental consciousness. It was also resulted from the research that children play an important role in the buying decision making of the consumers. According to (Thompson and Kidwell 1988) families which have children at their home were seen to be more active consumers' of green and organic products.

However, Magesson 2001 did not find any difference between families with children and without children to have the interest in purchasing the eco-friendly and green products. According to Sachin kumar and Dr Bhagwan Singh most of the North Indian consumers are well aware of the green or eco-friendly products. They identified that income, marital status, occupation have a strong relationship with awareness about organic marketing irrespective of their gender, age, state, area and education.

\subsection{Brand image}

It was also declared that consumer's awareness is the result of the web marketing or internet marketing and the initiatives taken by the government. A brand 
image is the perception of the consumers towards the product and set of beliefs concerning the brand. If a product has a strong brand image it corresponds with the personality of the consumer's. Further marketers can strengthen the image by advertising, promotions and packaging. When consumers think of a product, they think of a brand image and when they buy a particular product, they buy a brand. Branding requires a let if brain storming as company's need to project their brand in such a way that it reaches the mind of the customer's and makes a long lasting impact on their buying behaviour.

Kotler\&Armstrong 2010, have defined the brand positioning in 3 levels and suggested that marketers can use these levels in order to be successful in embarking in the consumer's mind. Best way to position a brand is to join it with the benefits it provides to the customers. It was seen that people remember the brand more with the benefits they preserve, without even he tangible product. Hence it is required to market the products in an efficient and effective manner, highest brand value comes with beliefs and values.

Another study done by Lautiainen,Tanja, 2015 stated that social, psychological and personal factors have impact on the consumer buying behaviour and it was further analysed from the empirical study that these factors have a relation between them and the decision making process. The results explained that friends, family and neighbours play a vital role in the consumer awareness towards the organic and green products. It was seen that friends have direct and positive impact, when in a friend circle a thing is discussed it is absorbed faster and with confidence and hence people are driven for a certain product irrespective of the knowledge of the consumer. Family and neighbours also influence the decision making of green or eco-friendly products, friends being the top most choice.

Hee Yeon Kim and Jae-Eun Chung described in their research "Consumer purchase intention for organic personal care products" discussed that consumer values which include health consciousness, environmental consciousness and appearance consciousness, perceived consumer behaviour control, attitude towards buying organic products, past experience with organic products are the main factors that impact the purchasing intention of the consumers who buy organic products. It was considered that people with high health consciousness, look deeper as compared to the consumers who are not at all conscious. They are interests in the products which are safe on skin and body and are seriously involved in the ingredients that a product is displaying. Secondly, environmental consciousness also push people to buy greener or organic stuff, such people are more concerned towards the deteriorating environment and hence to protect the environment they are ready to change their choices. They avoid products which harm the environment, tested on animals (Protehro, 1992), include synthetic and other chemicals .It was suggested that cleaner environment and environmental consciousness embarks a precondition for the organic or the green consumer. Last but not least, according to kim and chung appearance consciousness also helps people in deciding what to purchase and what not. It was resulted from the hypothesis that appearance consciousness is a main determinant of buying organic personal care products.

\section{Conclusion:}

After reviewing research papers, articles, websites, case studies it was inferred that consumer awareness is related to the consumer buying behaviour towards the organic or green products. Brand recognition is an important determinant of consumer awareness, as companies which cater the market and have captured the largest market share are the ones which are actively promoting green products. It was also declared that consumer's awareness is the result of the web marketing or internet marketing and the initiatives taken by the government. Consumer's level of environmental concern is related to their consideration and willingness for buying the natural, eco-friendly or green products Awareness effect is also mediated by the price. It was also seen that there exists a gap between the attitude of the people towards the green products and actual purchase of the organic or green products. People who go for purchasing organic products or green products are mainly women, some studies revealed that younger generation is also active in buying the organic products, however families with children were also admitting to have an interest in the eco-friendly products. Some studies have defined that the attributes of the product like healthiness and quality, mainly drive consumers towards the green purchase behaviour. Consumers take into account the benefits products provide to the individual as well as to the nature or society. Some authors have said that knowledge has no impact on the buying behaviour of people towards the organic or green products. But a deeper understanding of the benefits of green products make the consumers shift towards purchasing green or organic products. Consumer values which include health consciousness, environmental consciousness and appearance consciousness, perceived consumer behaviour 
control, attitude towards buying organic products, past experience with organic products are the main factors that impact the purchasing intention of the consumers.

\section{REFERENCES}

[1] Ahmad, S.R.B. and Juhdi, N., 2008. Consumer's perception and purchase intentions towards organic food products: Exploring the attitude among Malaysian consumers.

[2] Ali, A., Khan, A.A. and Ahmed, I., 2011. Determinants of Pakistani consumers' green purchasing behavior: Some Insights from a developing country. International Journal of Business and Social Science, 2(3), pp. 217-226.

[3] Arbuthnot, J. and Sandra, L., 1975. A comparison of French and American Environmental Behaviors, Knowledge and Attitudes. International Journal of Psychology, 10(4), pp. 275-281.

[4] Attas, D., 1999. What's wrong with "deceptive" advertising? Journal of Business Ethics, 21(1), pp. 49-60.

[5] Balderjahn, I., 1988. Personality variables and environmental attitudes as predictors of ecologically responsible consumption patterns. Journal of Business Research, 17(8), pp. 51-56.

[6] Bhattacharya, Sourabh (2011), "Consumer Attitude towards Green Marketing in India", The IUP Journal of Marketing Management, Vol. 10, No. 4 , pp. $62-70$

[7] Bamberg, S., 2003. How environmental concern does influences specific environmentally related behaviors? A new answer to an old question. Journal of Environmental Psychology, 23(1), pp. 21-32.

[8] Berkman, H.W. and Gilson, C.C., 1978. Consumer behavior-concepts and strategies.7th ed. Belmont, California: Dickenson.

[9] Byrne, P.J., Toensmeyer, U.C., German, C.L. and Muller, H.R., 1991. Analysis of consumer attitude toward organic produce purchase likelihood. Journal of Food Distribution Research, 22(2), pp. 49-62.

[10]Calfee,J. and Ringold, D., 1988. Consumer skepticism of advertising: What do the polls show? In: M.J Houston, ed. 1988. Advances in consumer research.. Provo, UT: Association for Consumer Research, pp. 244-248.

[11]Canavari, M., Nocella, G. and Scarpa, R., 2003.
Stated willingness to pay for environmentfriendly production of apples and peaches: webbased vs. in person surveys. In: EAAE, the $83^{\text {rd }}$ EAAE Seminar. Chania, Greece, 4-6 September 2003. s.l: s.n.

[12]Carlson, L., Stephen, J. and Kangun, N., 1993. A content analysis of environmental advertising: A matrix approach. Journal of Advertising, 22(3), pp. 27-40.

[13]Catoiu, I., Vranceanu, D.M. and Filip, A., 2010. Setting fair prices - Fundamental principle of sustainable marketing. Amfiteatru Economic, XI(27), pp. 115-128.

[14]Chan, T.S., 1996. Concerns for environmental issues and consumer purchase preferences: A two country study. Journal of International Consumer Marketing, 9(1), pp. 43-55.

[15]Chan, R.Y.K. and Lam, J.C., 2002. Prediction of pollutant emission through electricity consumption by the hotel industry in Hong Kong. International Journal of Hospitability Management, Iss. 21, pp. 381-391.

[16]Chase, D. and Smith, T.K., 1992. Consumers keen on green but marketers don't deliver.

[17] Advertising Age, 63(29), pp. 2-4.

[18]Chinnici, G., Amico, M. and Pecorino, B., 2002. A multivariate statistical analysis on the consumers of organic products. British Food Journal, 104(3-5), pp. 187-199.

[19]Cornelissen, G., Pandelaere, M., Warlop, L. and Dewitte, S., 2008. Positive cueing: Promoting sustainable consumer behaviour by cueing common environmental behaviours as environmental. International Journal of Research in Marketing, Iss. 25, pp. 46-54.

[20]Dunlap, R.E. and Mertig, A.G., 1995. Global concern for the environment: Is affluence a prerequisite? Journal of Social Issues, 51(4), pp. 121-137.

[21]Dunlap, R.E., Van Liere, K.D., Mertig, A.G. and Jones, R.E., 2000. Measuring endorsement of the new ecological paradigm: A revised NEP scale. Journal of Social Issues, 56(3), pp. 425442 .

[22]Ellen, P.S., Wiener, J.L. and Cobb-Walgren, C., 1991. The role of perceived consumer effectiveness in motivating environmentally conscious behaviours. Journal of Public Policy and Marketing, 10 (2), pp. 102-117.

[23]Elangovan ,A., Murugesan, B., \& Azhagaiah, 
R.(2006), "Consumers Attitude and Behaviour Toward Environmental Marketing", Udyog Pragati, The Journal for Practicing Mangers, Vol. 30, No. 4, pp.37-43.

[24]Fierman, J., 1991. The big middle in green marketing. Fortune, 3, June Iss., pp. 91-101.

[25]French, W.A., Barksdale, H.C. and Perreault Jr, W.D., 1982. Consumer attitude towards marketing in England and the United States. European Journal of Marketing, 16(6), p. 20.

[26]Frietzche, D. and Duecher, R., 1982. The effect on ecological concern on product attribute quality. American Marketing Association Proceedings. Chicago: American Marketing Association.

[27]Fryxall, G. and Lo, C., 2003. The influence on environmental knowledge and values on managerial behaviours on behalf of the environment: An empirical examination of managers in China. Journal of Business Ethics, Iss. 46, pp. 45-59.

[28]Gil, J.M., Garcia, A. and Sanchez, M., 2000. Market segmentation and willingness to pay for organic products in Spain. International Food and Agribusiness Management Review, 3(2), pp. 207-226.

[29]Grunert, S., 1993. Everybody seems concerned about the environment but is this concern reflected in Danish consumers' food choice? European Advances in Consumer Research, Iss. 1, pp. 428-433.

[30]Kronrod, Ann, Grinstein, Amir and Wathieu, Luc (2012), "Go Green! Should Environmental Messages Be So Assertive?" Journal of Marketing, Vol. 76 No. 1, pp. 95-102

[31]Wannimayake, W.M.C.B. and Randiwela, P. (2008) "Consumer attractiveness towards Green Products of FMCG sector: An empirical study" Oxford Business and Economics Conference Program

\section{Websites:}

www.greenmarketing.net/stratergic.html

www.cohnwolfe.com/en/ideas-insight/white-

papers/green-brands-survey-2011

http://en.wikipedia.org/wiki/Green_marketing

www.emeraldinsight.com/0263-4503.html

www. Businesswireindia.com.

www.greenpeace.org/international

http://www.projectguru.in/publications/green- $\underline{\text { marketing-in }}$

https://www.iisd.org/business/markets/green_who.as px 